\title{
FEATURES OF TOURIST ROUTES IN THE REPUBLIC OF SAKHA: EXTREME TOURS, UNIQUE NATURAL SITES, ARCHAEOLOGICAL AND RITUAL ATTRACTIONS
}

\author{
aYuriy A. Sleptsov*, bSargylana V. Nikiforova, 'Konstantin Y. Meshcheryakov, dOlga V. Skrobotova, \\ dRaisa M. Ivanova \\ ${ }^{a}$ nstitute for Humanities Research and Indigenous Studies of the North of Siberian branch of the Russian Academy of \\ Sciences, Yakutsk, Russian Federation \\ ${ }^{b}$ North-Eastern Federal University, Yakutsk, Russian Federation \\ cSaint Petersburg State University, Saint Petersburg, Russian Federation \\ dBunin Yelets State University, Yelets, Russian Federation.
}

\section{ART ICLE INFO}

\section{Article History}

Received: April 21, 2021

Revised: July 1, 2021

Accepted: July 30, 2021

\section{Keywords}

Recreational values

Eco-tourism

Tourist potential of Yakutia

Unique nature

Ritual attractions

\section{A B S T R A C T}

\begin{abstract}
Tourism is an important element of the social and economic development of Russia. The northern territories play an important role in the development of the Russian economy in general and the tourism industry in particular. Nordic tourism involves careful respect for environmental and social sustainability, the promotion of traditional local knowledge and value systems, and the preservation of local cultural heritage and cultural landscapes. The article analyses the promotion of the tourism potential of Yakutia. The northern territories of Russia are rich in natural resources and economic potential but do not have an effective tourist infrastructure due to the harsh climate and vast territories of permafrost. The study presents the results of the analysis of the main tourist routes of the Sakha Republic. The main factors for the development of tourism were determined by a set of landscape characteristics (unique nature of the Lena River, biological diversity of flora and fauna), ethnocultural and historical context, as well as infrastructure considerations (proximity to the capital, inexpensive transport, and engineering systems). The study demonstrated that scientific tourism in Central Yakutia is quite real and has great prospects due to the unique landscapes. It can also give impetus to new scientific discoveries. Defining and describing cultural landscapes, collecting field materials and mapping cultural and landscape zoning can simplify the work for the creators of tourist routes in the future.
\end{abstract}

Corresponding Author: Yuriy A. Sleptsov

Email: sleptsov5220@uoel.uk

(C) The Author(s) 2021.

\section{INTRODUCTION}

Territorial differences create different preconditions for regional development in the context of natural conditions, resources, and historical heritage. The North is the largest of the remaining territorial reserves; its resource potential is enormous. The development of tourism in the North can be considered as one of the ways to explore the new northern lands, where each of the northern nations has its unique regional characteristics. The potential of a region depends on the attractiveness of the territory, the level of national economic development, infrastructure, national mentality, and legislation. Recently, the number of tourists wishing to visit the North has considerably increased. The growing popularity of sustainable recreation has led to the emergence of new forms of 
tourism, as well as new forms of recreation in this area (Savvinova and Pakhomova, 2020). Among the main reasons for the growing popularity of northern tourism are significant congestion on traditional mass tourist routes, global warming, and the development of transport. Environmental and ethnographic factors play a key role in the development of northern tourism. The indigenous population has retained their traditional way of life, while the traditional management of natural resources is becoming the main factor in the development of northern entrepreneurship (Kamičaitytè-Virbašienè et al., 2018).

The unique natural resources found in the Republic of Sakha (Yakutia), Russia, greatly contribute to the development of tourism, which, thus, can become an alternative economic activity and a source of income. In Yakutia, you can enjoy the wild density of taiga forests, vast areas of tundra, the harsh beauty of mountain ranges, icy landscapes of the Arctic and the unique culture of indigenous peoples. Although the local climatic conditions are not favourable for many types of recreation, the most promising forms of tourism include ecological, sports, cruise, ethnographic, social, rural, business, research, and educational forms (Kirillov et al., 2020). Possessing unique and enormous tourist and recreational resources, the Republic of Sakha (Yakutia) is increasingly attracting the attention of tourists and foreign investors and has all the opportunities and conditions to become one of the main tourist destinations in Russia. "The development of the tourism industry in the republic is one of the long-term priorities of socio-economic development. Inbound and domestic tourism have been selected as the priority directions of tourism development in the Republic of Sakha (Yakutia). Inbound tourism is a priority export-oriented industry. Its development requires considerable investments in improving the material base and consulting. Domestic tourism is seen as an import-substituting industry and as an important source of income for budgets of all levels" (Aksenova et al., 2020).

\section{MATERIALS AND METHODS}

The theoretical basis for the study included modern foreign concepts and scientific developments of Russian and foreign scientists, identifying, first of all, the features of the development of the tourism sector and its structure; secondly, the development of organisational and managerial tools and mechanisms for the development of tourism and assessment of its impact on the recovery growth of the republic's economy. In the process of the study, conventional techniques and methods of economic analysis were used, such as grouping, comparison, and generalisation, as well as economic-mathematical and statistical methods: the method of fuzzy sets, the construction of matrices and graphs in relation to socio-economic objects. The empirical basis of the study included statistical data and reports of the World Tourism Organisation, official statistics bodies of foreign countries, the Federal State Statistics Service of the Russian Federation, regional state statistics bodies, in particular, the territorial body of the Federal State Statistics Service of the Chechen Republic, regulations of Russian and foreign 6 authorities, review and analytical materials, scientific reports and articles published in periodicals and the Internet, the author's personal research (Nikolin, 2020). To achieve the purpose of the study, the authors of have chosen the following lines of study: to rethink the category of regional tourism, fill it with content that meets the essence of this phenomenon in the system of modern practical coordinates; to specify the essence of regional tourism as a systemic institution for assessing the financial independence of residents of neighbouring regions; to determine the main tasks and subject-object features of the administrative management of the Sakha Republic, managerial decisions and activities of public authorities; to clarify the role of the implemented tourism development programmes in changing the flow of tourists in the region; to actualise the tasks of professional training of administrative staff of a new generation, capable of analytical activities in the public sphere, and to introduce innovative methods of task administration to create an effective programme for the development of the region's tourism potential (Voronkova et al., 2020).

When writing the study, general scientific and special methods were used: the method of systems analysis is a methodology of systems theory, which lies in studying any objects represented as systems, carrying out their structuring and subsequent analysis. The main feature of systems analysis is that it includes not only methods of analysis, but also methods of synthesis. The main purpose of systems analysis is to detect and eliminate uncertainty in solving a complex problem based on finding the best solution from existing alternatives. The systems analysis helped analyse the existing 
programmes for the development of the tourism potential of the Sakha Republic, their strengths and weaknesses, to highlight the points that are important to update. Content analysis is a method of qualitative and quantitative study of the content of messages in order to obtain reliable information about social reality (Khompodoeva, 2017). The use of this method involves the algorithmised selection of certain content elements in the text, their classification in accordance with a previously developed scheme, the subsequent calculation of the selected content elements and a quantitative presentation of the results. Using this method, it was possible to identify the main provisions of existing programmes for the development of tourism. Also, this method helped analyse theoretical historical materials, to identify data that can be used to attract tourists to the region. Benchmarking is a powerful and versatile tool that enhances the ability to understand and describe political processes and changes in any country in accordance with the existing reality, concepts, and goals facing any political system. With the help of a comparative analysis, the advantages of various tourist points, their attractiveness for visitors to the region, the features of various attractions and the possibility of their advertising in the future were determined (Zola, 2017).

\section{RESULTS AND DISCUSSION}

Inbound tourism emerged in Yakutia with the beginning of perestroika, socio-economic and political transformations that began in 1985, when the republic was visited by up to 1.8 million tourists a year. During the recession years, that number dropped sharply to 60 visits. To date, there is a stable growth and development of both inbound and domestic tourism in the republic. As of 2013, 3.000 foreign tourists visited the republic, which is $66 \%$ less than in 2005 (4.700 tourists). Most of the visitors come from Germany (26.4\%) and China (23.8\%). International tourists prefer extreme travel, for example, visiting the village of Oymyakon ("Pole of Cold" tour), Verkhoyansk (climbing the sacred mountains Kisilyakh), as well as the national parks Lena Pillars and Buluus (Aksenova et al., 2020; Tarasov, 2021; Voronkova et al., 2020).

As prices for air tickets rise in the republic, there is a steady growth in domestic tourism. 5-6 years ago, local travel companies were mainly engaged in outbound tourism. Currently, domestic tourism continues to develop, new routes are opening in various regions of the republic. Among the most popular tours are river cruises along the Lena Pillars, hunting and fishing, the Pole of Cold festival, visits to protected areas (national parks, Ust-Lensky nature reserve), as well as cultural and educational events, such as "Yakutsk and its environs". The main types of domestic tours are weekend tours, event tours, and various social tourism activities such as youth or senior tours (Nikolaeva et al., 2015).

The domestic tourism market in the republic is seasonal in nature, the peak falls in July - early August, when weekend tours to the regions adjacent to Yakutsk, cruises along the Lena and rafting tours are in great demand. The domestic tourism market is dominated by holidaymakers from the republic, mainly city dwellers. In recent years, there has been an increase in demand for tourism products of the republic from Russian tourists from such large cities as Moscow, St. Petersburg, Yekaterinburg, Novosibirsk, and others. According to Rosstat data for 2013, 8.700 people used the services of travel companies to travel across Russia. This is $24.5 \%$ of the total number of tourists. The most popular destinations for domestic tourism were Krasnodar Territory (21.3\%), Moscow (10.6\%) and Altai Territory (4.7\%). Intra-republican tourism accounts for $61 \%$ of the total (Burkaltseva et al., 2020).

The specificity of tourism in Yakutia determines the principle of five "Es": ecology, ethnos, extreme, exotic, and exclusive, noted the ex-minister of entrepreneurship and tourism of the Republic of Sakha (Yakutia) Ekaterina Kormilikina (Zalutskaya et al., 2015). Nowadays, the Republic of Sakha (Yakutia) attracts foreign tourists due to its national culture and exotic elements.

The leader in the development of tourism in the Sakha Republic is the Khangalassky region. Its tourist attractions are divided into three clusters: the tourist and recreational complex Orto-Doydu, Samartai, and the Lena Pillars Nature Park. In 2013, the region was visited by 200.000 tourists. Khangalassky district has a powerful tourist and recreational potential, with unique natural complexes located in the immediate vicinity of the capital, with a convenient transport scheme and on the banks of the Lena. The latter helps to promote ecological, fishing/hunting, adventure, historical and cultural tourism, as well as a number of other forms of tourism. For this reason, tourism in the region is considered as one of the priority areas of the urban economy, along with the production of building 
materials and agriculture. Historical and cultural potential is an important advantage of the Khangalassky region. Numerous objects of cultural heritage are concentrated here, the specificity of which is determined by their predominant archaeological and ethnocultural nature, which performs an important social function: archaeological materials are exhibited in local museum complexes; annual festivals are held. The historical heritage of the post stations, once located along the Irkutsk-Yakutsk postal passage, is preserved and used to create tourism goods. The cultural landscape includes architectural monuments, archaeological sites, museums, monuments, etc. Some of them are included in the Unified National Register of Cultural Heritage Objects of the Peoples of Russia, while others are undergoing certification (Zamorshchikova and Khokholova, 2020).

Being potentially very attractive territories for scientific tourism, the natural and cultural landscapes of Yakutia are described by unique physical and geographical processes. The only existing specialised institute of permafrost of the Siberian Branch of the Russian Academy of Sciences, located in Yakutsk, makes a considerable contribution to the study of the centuriesold layers of permafrost and unique landscapes of permafrost (alases, baidzherakhs, bulgunnyakhs, yedomas). The Institute cooperates with many countries of the world (China, Mongolia, South Korea, Germany, Canada, USA, Japan, and France). The Institute's researchers also take part in international Arctic programmes that are of interest to many scientific researchers around the world. These programmes also contribute to the development of scientific tourism in Yakutia. The staff of the Institute carry out research to study the evolution of the permafrost zone under the influence of natural and anthropogenic factors; they also assess the thermal and mechanical effects of engineering structures on the layers of permafrost soil. Another aspect of the study is fundamental and applied research in the field of geological cryology (study of permafrost), including the classification of landscapes (Tourism industry development, 2009).

Currently, the problem of landscape classification remains unsolved due to its high complexity. Scientists continue research in this area (Zamorshchikova and Khokholova, 2020). The choice of classification was made in favour of the method proposed by F. Milkov as fundamental for the study of the Yakut landscape. This classification has several advantages: the independence of taxonomic data in general and of each taxonomic unit in particular, namely, geological and geomorphological, as well as biohydroclimatic data. This creates a universal classification system for contrasting areas. Another advantage of this classification is its compliance with the main approaches to identifying natural and territorial complexes with different characteristics of permafrost. Milkov's idea of the organisation and principles of landscape differentiation is presented in his taxonomic system, which considers three main areas of differentiation of the natural environment: regional complexes, typological complexes, and paragenetic complexes. Regional complexes are genetically uniform, territorially integral and unique landscape complexes. Typological complexes are morphologically uniform, genetically diverse landscape complexes with a discontinuous range. Paragenetic complexes include systems of contiguous and genetically related regional and typological complexes. Each range constitutes an independent selection of units, each of which is used for specific purposes: regional complexes are used for zoning; typological complexes are used for mapping; paragenetic complexes are used for systematic landscape analysis. Proceeding from the foregoing, A. Fedorov suggested adding one more criterion to the basis of typological zoning, taking into account the layers of the permafrost zone. This criterion currently underlies the landscape zoning of Yakutia. The principles underlying this taxonomic system allow to more rationally solve the problems of "horizontal" classification of permafrost landscapes and their mapping. This system was rebuilt to conduct research in the development of permafrost layers and assess the level of sustainability of permafrost landscapes (Atakova, 2019).

The problems of studying the stability of the frozen landscapes of Yakutia and the adaptation of the population to the landscape and climatic changes are the main direction of scientific research, tourists and photographers who are interested in the results of scientific research in one of the regions of the Russian Federation. The cultural landscape constitutes an entire complex of features of the lifestyle of ethnic groups in specific natural and geographical conditions. The surrounding geographical environment, the time of settlement and territorial development, various methods of fishing and hunting, as well as the national traditions 
of the peoples who inhabited these lands - all these aspects had a considerable impact on the development of the cultural landscape. Currently, there are very few landscapes that have not experienced the direct or indirect impact of human activities. In turn, landscapes that were inevitably involved in human activities, play a crucial role in the development of consciousness, an aspect that is reflected in culture and various social and economic processes.

Meanwhile, ethnocultural landscapes in Russia have been understudied, especially in the polyethnic northern territories. When studying the cultural landscape of Yakutia, the Republic, which constitutes a vivid example of a multi-ethnic territory, researchers mainly pay attention to the ethnocultural approach, which is associated with a wide variety of natural, ethnological, cultural, and economic features of the territory of Yakutia. Specific aspects of the ethnocultural landscape include: ethnic composition, dermal diffusion, culture, history of the territorial development of Yakutia and economic development. These aspects have been described by ethnologists, historians, ethnographers, and geographers in their major works (Eidelman et al., 2019).

Territorial differences create different predispositions for regional development in the context of natural conditions, resources, and historical heritage. The North is the largest of the remaining territorial reserves; its resource potential is enormous. The development of tourism in the North can be considered as one of the ways to explore the new northern lands, where each of the northern nations has its unique regional characteristics. The potential of a region depends on the attractiveness of the territory, the level of national economic development, infrastructure, national mentality, and legislation. Recently, the number of tourists wishing to visit the North has significantly increased. The growing popularity of sustainable recreation has led to the emergence of new forms of tourism, as well as new forms of recreation in this area. Among the main reasons for the growing popularity of northern tourism are considerable congestion on traditional mass tourist routes, global warming, and the development of transport. Environmental and ethnographic factors play a key role in the development of northern tourism. The indigenous population retained their traditional way of life, while the conventional management of natural resources is becoming the main factor in the development of northern entrepreneurship (Zalutskaya et al., 2015).

The unique natural resources found in the Republic of Sakha (Yakutia), Russia, greatly contribute to the development of tourism, which, thus, can become an alternative economic activity and a source of income. In Yakutia, one can enjoy the wild density of taiga forests, vast areas of tundra, the harsh beauty of mountain ranges, icy landscapes of the Arctic and the unique culture of indigenous peoples. Although the local climatic conditions are not favourable for many types of recreation, the most promising forms of tourism include ecological, sports, cruise, ethnographic, social, rural, business, research, and educational tourism (Borissova et al., 2017a).

Apart from the extreme and cruise tourism, which are already quite developed types of tourist activities in the republic nowadays, the following types of tourism are very promising for development: Fans of ethnographic tourism, as well as gastronomic tours, may be interested in the Yakutsk Museum of Local Lore, settlements on the territory of Yakutia where ritual carriers have survived, customs, traditions, and beliefs of the indigenous smallnumbered peoples of the North, unique local cuisine made from natural products (slices of frozen fish or meat served cold, koumiss, colt), as well as the annual Ysyakh summer holiday in the Uskhatyn area. Every year at the end of June, many guests from all over the republic, from other regions of Russia and from abroad come to Yakutsk to celebrate Ysyakh. Yakutia is primarily known in the world as one of the most recognisable cold inhabited places on the planet. However, in recent years, Yakutia has been actively developing summer tourism. Most tourists come at the end of June to visit the Ysyakh festival.

The festival, which currently attracts 150.000 people over two days, is one of the best examples of the successful revival and reconstruction of traditional cultural practices and spiritual heritage that were partially lost during the Soviet era (Semenov et al., 2014). Ysyakh is a Yakut national holiday. According to the Yakut calendar, the longest day began on June 22 the first day of the solstice. It served as a signal for the beginning of the organisational ritual holiday Ysyakh meeting the New Year. Ysyakh is a traditional holiday of the Sakha people, personifying the welcome of summer, the awakening of nature, blessing the unification of the forces and capabilities of the people for creation, 
prosperity, and abundance. During Ysyakh, the inner world of the people is most fully revealed, which, through ancient, sacred rituals and ceremonies, reflects the way of life, moral principles, customs and worldview of the people, expressing the triumph of harmony between the Human and the World, between the results of human labour and nature, united by a single rhythm. On Ysyakh people adhere to festive etiquette.

Osuokhai is a traditional circular dance of the Yakuts. Its active propaganda is one of the vivid examples of the restoration of traditional spiritual values and the entire system of folk knowledge through folk dance.

It is known that traditional dance, along with other phenomena of ethnic culture, is an object of symbolisation. In the ritual, a circle dance absorbs and reflects all its iconic elements. The specificity of dance as an element of a ritual presupposes the presence of participants, an addressee, an object of ritual influence, a special time of performance, a ritual place of performance, ritual attributes, special clothes, songs or music. The traditional dance osuokhai originally incorporated the mechanism of ethnic education. Folk dance training at the present stage constitutes an entire educational process, which includes the transfer of knowledge of both spiritual and material culture of the ancient Yakuts. In this process, an equal place is given to the study of traditional choreography, and history, and ethnography of the ethnos (Bunakov and Rubtzov, 2016).

Traditional (ritual) Yakut dances are cultural phenomena aimed primarily at adapting to the natural environment and protecting society from its "evil" forces. The most indicative in this regard is the Osuokhai circular dance of the Yakuts. Making a roundabout by ritual walking-trampling on Ysyakh (traditional New Year holiday among the Yakuts) around the sacred centre of the developed space, the symbolic embodiment of which is the World Tree Aal Kuduk Mas, performs the function of cleansing - protecting this space from the corruption of Chaos, as well as modelling a new "clean" space. Prosperity was achieved on Ysyakh through a ritual sacrifice with the obligatory performance of a circle dance around the World Tree. It was believed that the circle dance has a magical ability to reach a remote "alien" world, and one of its ritual functions is to "raise the soul" of a sacred animal to heaven. Thus, through the lens of the preservation and development of the Yakut circle dance, the viability and cultural integrity of the entire ethnos in new historical conditions is well traced.
Socially-oriented tourism is extremely important not only for physical recovery and active recreation, but also for the moral and national-patriotic education of children and youth, it is necessary to restore the system of children's labour and recreation camps, camps for patriotic education in all uluses of the republic. Unique finds of burials of mammoths and other representatives of the preglacial period, sites of ancient people, as well as the presence of permafrost throughout the republic, tours "Journey to the Pole of Cold", places of the Stalinist camps "GULAG", Museum of Mammoth, Museum of History and Culture of the Peoples of the North, tourist complex "Kingdom of Permafrost", the Treasury of Yakutia, the Institute of Permafrost Science with the possibility of descending into underground mines, is an invaluable advantage for the development of scientific and educational tourism. The government of the republic is also taking various measures to restore extinct species of large animals and expand the biological diversity of the animal world in Yakutia, the population of musk oxen is being restored, and American bison are successfully adapting. Ecotourism is currently a very promising type of tourism all over the world, and it has the following interesting directions that can be developed in Yakutia: educational, scientific and sports. The World Tourism Organisation interprets the term "adventure tourism" as a broader concept that includes ecotourism. In addition, terms such as "sustainable tourism" and "green tourism" are widely used to refer to ecotourism. Agritourism, one of the types of ecotourism, is also becoming more common. This is tourism in rural areas, where tourists live on farms and estates, doing agricultural work. Low population density, abundance of natural resources, and a relatively low level of presence of industrial facilities favour the development of this particular type of tourism in the region (Borissova et al., 2017b).

To further develop tourism, the administration of the Khangalassky region has elaborated a tourism development project, which, in turn, may become a pilot project for establishing a number of effective tourism enterprises in the republic. The cluster approach is the basis for the development of tourism in the Khangalassky region. Its territory is divided into three clusters:

-Tourist and recreational cluster "Orto Doydu", located at $49 \mathrm{~km}$ of Pokrovsky tract in close proximity to Yakutsk.

-Tourist and recreational cluster "Samartai", 
which includes the museum complex "Samartai", tourist complex "Buluus", "Kuruluur" and the water park "Kyzyl Syr".

-Tourist and recreational cluster "Lena Pillars", which includes Diring-Yuryakh, the Sinyaya and Buotama rivers, the hotel complex "Serkin Sekhen", as well as some others.

\section{CONCLUSIONS}

The current level of tourism in Yakutia, the state of the material base of related and infrastructural industries, the services sector, designed to ensure the progressive development of tourism activities, do not correspond to the world level and the requirements of the tourism industry. Thus, the tourism industry in the Republic of Sakha (Yakutia) is at an early stage of development. However, there is a huge number of specially protected natural areas and reserves on the territory of Yakutia, which in the future may become the basis for the development of new tourist routes. The implementation of projects and programmes for the development of industry in Yakutia presupposes the development of infrastructure within the republic, which would contribute to the creation of conditions for the development of domestic and inbound tourism, the expansion of geography and the establishment of new tourist bases and complexes.

Natural landscapes and objects of historical and cultural heritage of the Sakha Republic are the basis for the development of scientific tourism. However, these territories admittedly lack the necessary infrastructure, which is one of the main factors in the socio-economic and environmentally effective development of scientific tourism. The recognition of these objects as potential areas of scientific tourism and the creation of the necessary infrastructure will help develop the foundations of a new and promising tourist destination and increase the tourist flow in the region. In general, the selected cultural and landscape territories reflect the spatial natural, ethnocultural, and historical and cultural features of individual parts of the Sakha Republic and are not final. Further, in the process of this zoning, it is possible to include socio-economic and economic factors. This aspect would allow the use of cultural and landscape zoning for the purposes of territorial planning.

\section{REFERENCES}

Aksenova, E. I., G. D. Petrov, E. V. Chernyshev and N. N.
Yudina. 2020. Recreational potential of medical tourism of Russia. Problems of Social Hygiene Public Health and History of Medicine, 28.

Atakova, S. 2019. The current state of tourism development in the Republic of Sakha (Yakutia). The way of science: 37-40.

Borissova, A., E. Andreeva, N. Zaitseva, A. Larionova and A. Mayorova. 2017a. Perspectives for the development of ethnic, eventual and culturalcognitive tourism in the republic of Sakha (Yakutia). Man in India, 97: 149-157.

Borissova, A. A., T. A. Protopopova, N. N. Alexeeva, A. A. Petukhova and N. A. Zaitseva. 2017b. The use of the concept of three layers of archaic in the design of a regional tourist product. Man In India, 97: 341-347.

Burkaltseva, D., S. Tsohla, A. Yanovskaya, O. Guk, A. Zharova and S. Polskaya. 2020. Analysis of the Functioning of the Tourist and Recreational Industry in Conditions of Restrictions. Journal of Environmental Management \& Tourism, 11: 19021914.

Eidelman, B. M., O. A. Bunakov, N. A. Zaitseva, A. A. Larionova, A. M. Nayda, N. V. Dmitrieva and E. V. Dashkova. 2019. Problems and prospects for the development of ecological tourism in the Russian federation. Journal of Environmental Treatment Techniques, 7: 566-571.

Kamičaitytė-Virbašienė, J., V. Filippova, A. Savvinova, Y. Danilov and S. Gadal. 2018. The Study of Cultural Landscapes of Central Yakutia for the Development of Scientific Tourism. Journal of Sustainable Architecture and Civil Engineering, 21.

Khompodoeva, M. 2017. On the issue of tourist and recreational zones in Yakutia. 4th International Multidisciplinary Scientific Conference on Social Sciences and Arts SGEM2017, Modern Science.

Kirillov, S., N. Sedova, M. Slipenchuk and E. Vorobyevskaya. 2020. Sustainable Tourism Development in Russia: The Case of Baikal Harbour Project. European Journal of Sustainable Development, 9: 179.

Nikolaeva, J. V., N. M. Bogoliubova and S. S. Shirin. 2015. Ecological tourism in the state image policy structure. Experience and problems of modern Russia. Current Issues in Tourism, 21: 547-566.

Nikolin, E. G. 2020. Local floras of the resource reserve "Verkhneindigirskiy". Botanicheskii Zhurnal, 105: 
627-645.

Savvinova, A. and L. Pakhomova. 2020. Recreation and Landscape Protection - with Sense Hand in Hand? Conference Proceedings. Mendel University in Brno, Brno.

Semenov, N. N., K. S. Gorokhova and B. I. Gerasimov. 2014. Peculiarities of tourism development in the Republic of Sakha (Yakutia). Young Scientists Forum: Public and economic sciences: electronic press on the XIX International Student Scientific Conference. MCNO, Moscow.

Tarasov, A. E. a. I. A. C. 2021. Perspectives of development of sports and recreational tourism in Yakutia. Theory and Practice of Physical Culture. http://www.teoriya.ru/ru/node/3365.

Voronkova, O. Y., S. N. Petrova, E. A. Ivanova, E. N. Klochko, E. V. Logvina and A. N. Penkova. 2020.
Assessment of the regional potential of recreation and health-promoting natural resources. Journal of Experimental Biology and Agricultural Sciences, 8: S314-S321.

Zalutskaya, S. Y., L. N. Pavlova and O. M. Salnikova. 2015. Today Problems and Cases of Territory Promotion: Yakutia and Kazakhstan. Review of European Studies, 7.

Zamorshchikova, L. and I. Khokholova. 2020. Winter destination: Peculiarity of tourism in the arctic. Paper presented at the Public Recreation and Landscape Protection - with sense hand in hand? Conference Proceedings. Mendel University in Brno, Brno.

Zola, L. 2017. The making \& unmaking of a sacred place: A case-study in the Sakha Republic (Yakutia). Shaman, 25: 181-196.

Publisher's note: EScience Press remains neutral with regard to jurisdictional claims in published maps and institutional affiliations.

Open Access This article is licensed under a Creative Commons Attribution 4.0 International License, which permits use, sharing, adaptation, distribution and reproduction in any medium or format, as long as you give appropriate credit to the original author(s) and the source, provide a link to the Creative Commons license and indicate if changes were made. The images or other third-party material in this article are included in the article's Creative Commons license, unless indicated otherwise in a credit line to the material. If material is not included in the article's Creative Commons license and your intended use is not permitted by statutory regulation or exceeds the permitted use, you will need to obtain permission directly from the copyright holder. To view a copy of this license, visit http://creativecommons.org/licenses/by/4.0/. 